\title{
Maxillary Reconstruction Using rhBMP-2 and Titanium Mesh. Technical Note About the Use of Stereolithographic Model
}

\author{
Reconstrucción Maxilar Utilizando rhBMP-2 y Malla de Titanio. \\ Nota Técnica sobre el Uso de Modelo Estereolitográfico
}

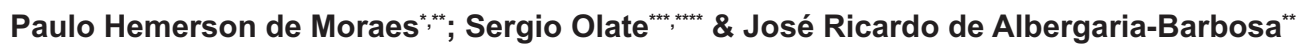

DE MORAES, P. H.; OLATE, S. \& ALBERGARIA-BARBOSA, J. R. Maxillary reconstruction using rhBMP-2 and titanium mesh. Technical note about the use of stereolithographic model. Int. J. Odontostomat., 9(1):149-152, 2015.

ABSTRACT: Maxillary reconstruction is a common procedure in maxillofacial surgery; for this purpose is used autogenous bone, alloplastic bone or another one with different results. In all of them, traditionally the use of computed tomography is used to make the surgical plan, however, 3D models are not used frequently. This report show a new application of the stereolithography to anticipate the surgical treatment of maxillary reconstruction, using a titanium mesh and rhBMP-2 to obtain a predictable surgical result with diminished surgical time.

KEY WORDS: maxillary reconstruction, rhBMP-2, titanium mesh.

\section{INTRODUCTION}

Maxillary atrophy in fully edentulous patients is a major clinical problem due the lost of hard and soft tissue, making a difficult choice in a full rehabilitation case.

The maxillary reconstruction has been used by the last 30 years to make sure an implant surgery with a good tridimensional position. Simplified surgical techniques minimize postoperative complications and tissue engineering holds great promise for many bone grafting procedures (van den Dolder et al., 2003).

The development of recombinant human bone morphogenetic protein 2 (rhBMP-2) has offered an alternative to traditional bone grafting, which has been considered the gold standard for oral and maxillofacial reconstruction. Collagen sponges alone cannot be used as a scaffold for rhBMP-2. Surgeries involving onlay grafts require use of absorbable or titanium mesh to hold the rhBMP-2-containing framework in place. However, determining the increase in bone volume needed for the rehabilitation using rhBMP-2 is a challenge for dental surgeons since it is difficult to reproduce, during the surgery, what has been planned.

The authors present a method to optimize surgical outcomes, reduce operating time and result in desired postoperative bone volume.

\section{METHOD}

A stereolithographic model was obtained from a three-dimensional computed tomography (3D CT) of the maxilla (Figs. 1 and 2). Atrophy of the alveolar bone (Fig. 2) was then revised and bone measurements were made using a ruler and compass in the $3 D C T$ to fabricate wax increments that would meet the volume needed for the reconstruction (Fig. 3). These increments were then placed on the maxilla and shaped to reproduce the desired bone volume initially planned.

Department of Customization, Bioconect Company, São Paulo, Brazil.

" Division of Oral and Maxillofacial Surgery, State University of Campinas, Campinas, Brazil.

*** Division of Oral and Maxillofacial Surgery \& CIMA, Universidad de La Frontera, Temuco, Chile.

${ }^{* * * * *}$ Center for Biomedical Research, Universidad Autónoma de Chile, Temuco, Chile. 


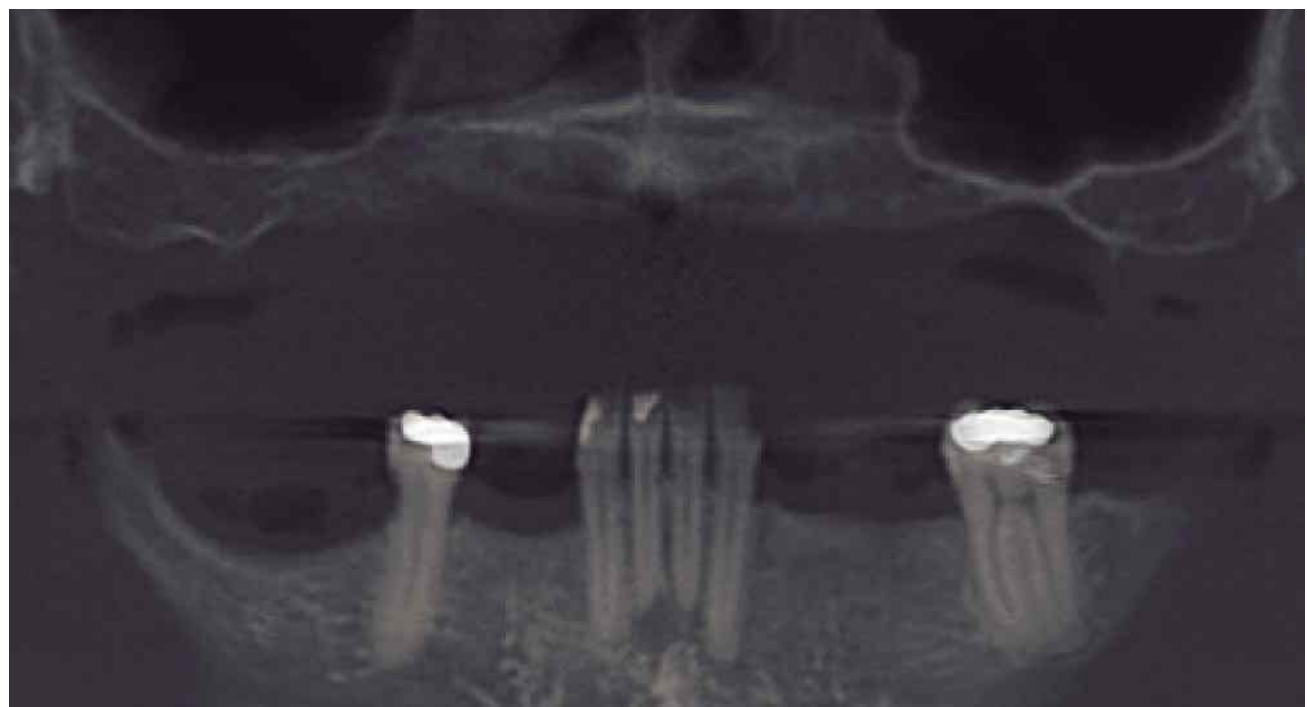

Fig. 1. Computed tomography in a panoramic view showing a fully edentulous patient with a big bone resorption in the anterior and posterior maxilla.

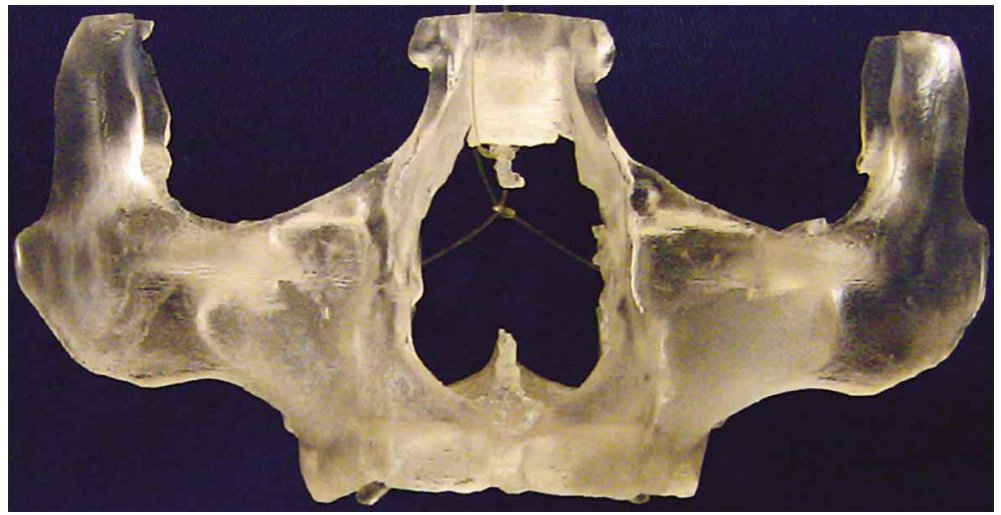

Fig. 2. Stereolthographic model obtained from the CT. Is observed an important bone lost in the anterior maxilla.

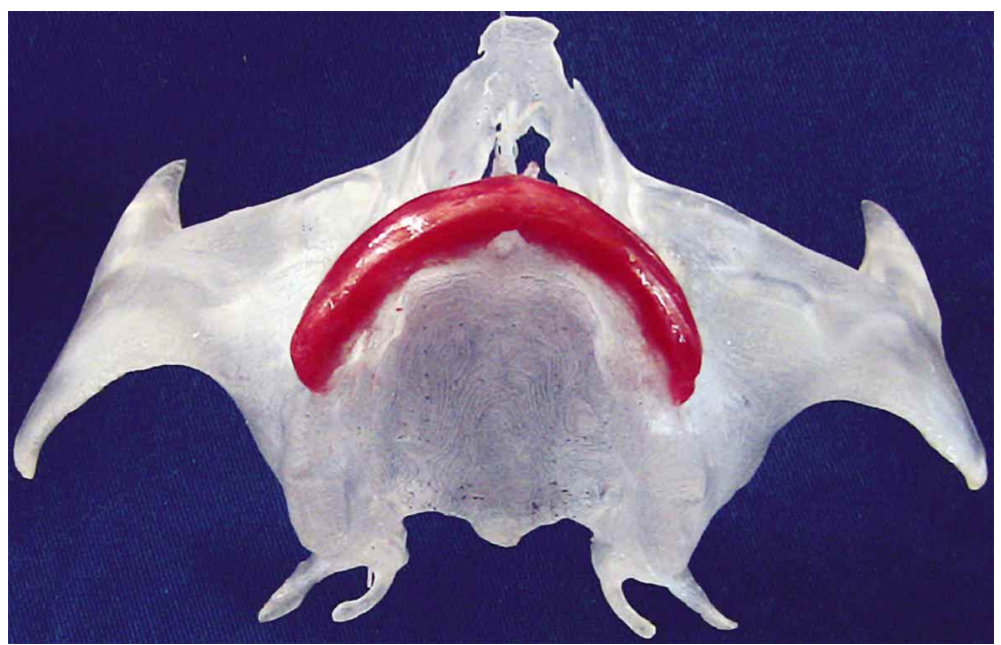

Fig. 3. Stereolthographic model with a wax in the alveolus, to make an augmentation procedure in relation to implant installation.
Next, a titanium mesh was trimmed and shaped to meet the dimensions of the wax increment (Fig. 4), as well as the area for mesh fixation (screws).

With regard to the surgery, vestibular approach was used to expose the maxilla. The incision is usually placed approximately 3 to $5 \mathrm{~mm}$ superior to the mucogingival junction. Leaving unattached mucosa on the alveolus facilitates closure. The surgeon should not make the incision more superior in the anterior region because entrance into the piriform aperture, with damage nasal mucosa.

After the maxillary vestibular approach, access to the maxillary sinus was carried out using an ultrasonic diamond bur (Satelec $®$, Action Group, Merignac, France). The sinus membrane was lifted and a rhBMP-2 containing collagen sponge inserted to increase bone height in the posterior maxilla. The preshaped mesh was then installed by initially fixing its superior part with screws. It was then filled with the sponge according to what was previously planned and its inferior part fixed (Fig. 5). Finally, a juxtaposition of the mucosa was attained with continuous sutures. 


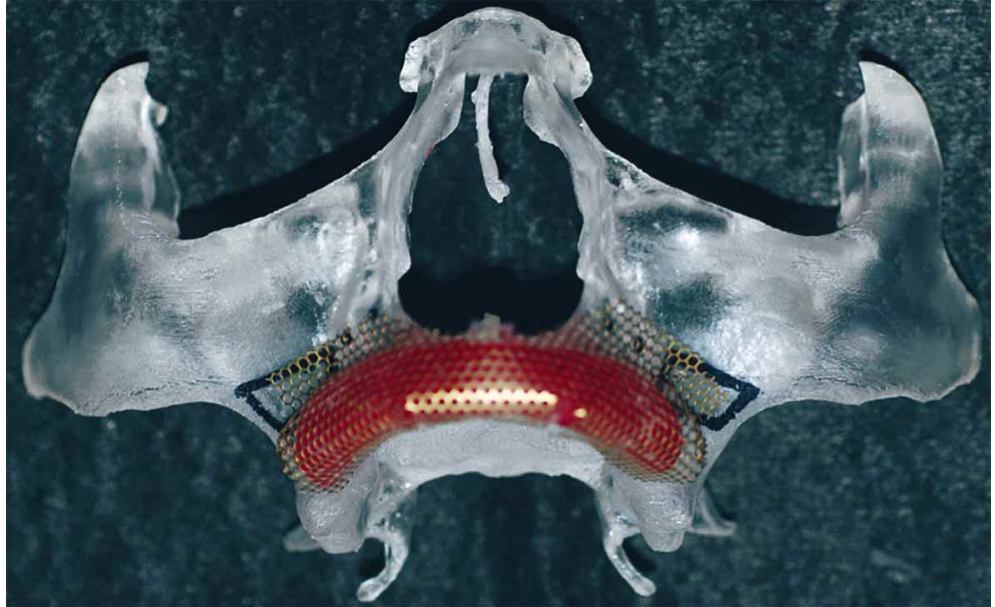

Fig. 4. Stereolthographic model with a wax and a conventional titanium mesh. The mesh is manipulate in relation to the bone graft.

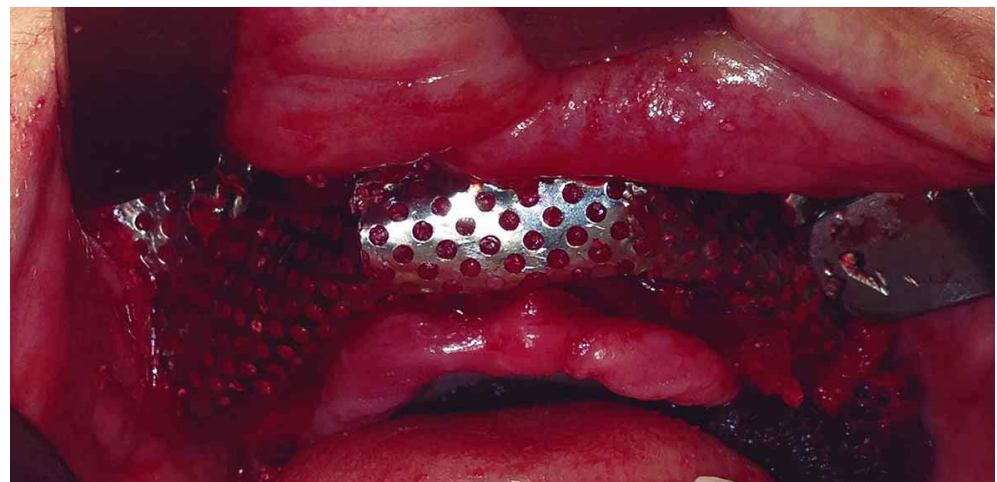

Fig. 5. Intra operative view showing a adequately adaptation of the titanium mesh.

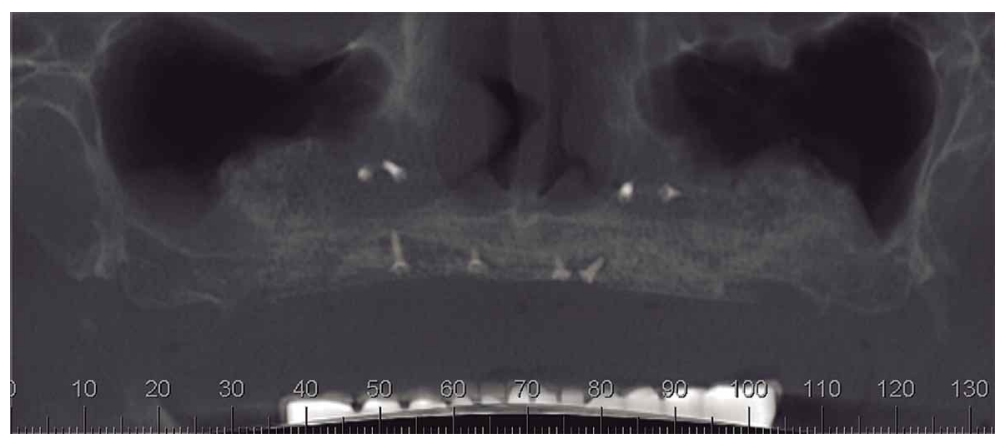

Fig. 6. Five months follow-up showing the screw position and the increase of bone.

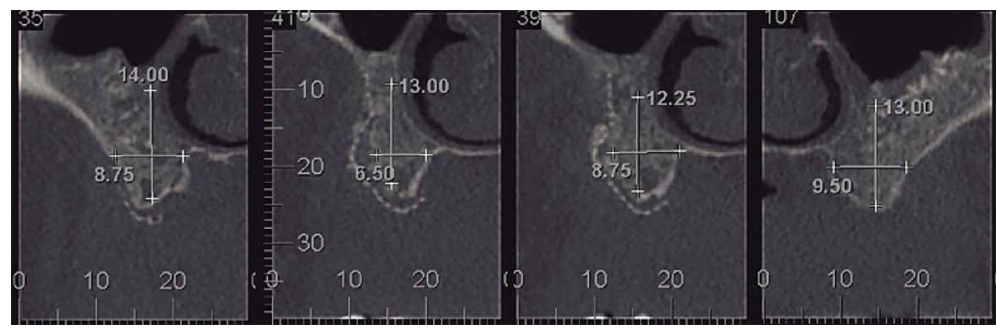

Fig. 7. Lateral view of the maxilla showing the titanium mesh position; the reconstruction is obtained using rhBMP-2
A 5-month follow-up was realized. The evaluation with 3D TC shows a bone augmentation without problem (Figs. 6 and 7). Was not observed exposure of the mesh and bone contouring was obtained.

\section{DISCUSSION}

Conventionally, maxillary bone reconstruction with rhBMP-2 is empirically carried out. The mesh is shaped during the surgery, thus making it difficult to quantify the bone volume needed for a reconstruction for secondary dental implants surgery. The vestibular approach is more likely to prevent tissue suture dehiscence due to the non-keratinized mucosa in this area.

This technique offers a surgical instrumentation that allows the surgeon to obtain a bone volume according to that pre-surgically planned. Moreover, it optimizes the surgical outcomes and reduces operating time. No postoperative complications regarding this technique has been reported.

The use of titanium mesh for maxillary reconstruction has been used in different conditions; in the 90's Kessler \& Hardt (1996), used titanium mesh to make a new support in the maxillary sinus lateral wall, showing success based in prevention of soft tissue prolapse and preservation of the facial contour. Liu et al. (2006), showing good results when was used in small or big oncologic resection Another research, show same results in big reconstruction of the palatomaxillary area (Sun et al., 2009). In post-traumatic deformity, titanium mesh is a good strategy to maintain the facial contouring (Arcuri et al., 2012).

For dental implant indications, the use of titanium mesh for reconstruction of the atrophic alveolus was first introduced by Dr. Philip Boyne in 1985, showing a follow-up of 15 patients for 3 to 10 year without problem. 
Louis et al. (2008), worked in 44 patients using porous titanium mesh; they reported that is a reliable containment system used for reconstruction of the maxilla and the mandible. This material tolerates exposure very well and gives predictable results.

For other hand, the graft material is an important topic because autogenous bone is a gold standard in this big reconstruction (Louis, 2010). Other materials as alloplastic or xenogenic bone are been used in minor reconstruction with different results; now, recombinant human bone morphogenetic protein 2 (rhBMP-2) permit a bone expression and reconstruction to obtain adequately results with minor morbidity (Lee et al., 2014).

This report show the efficiency of sterolithographic in surgical plan and represent a low cost and predictable surgical plan using a conventional titanium mesh. rhBMP-2 permit a quick graft step into the surgery due that the rhBMP-2 sponge not need a compression or pressure to fill the titanium mesh and, obviously, not need a donor site to make the surgery.

DE MORAES, P. H.; OLATE, S. \& ALBERGARIA-BARBOSA, J. R. Reconstrucción maxilar utilizando rhBMP-2 y malla de titanio. Nota técnica sobre el uso de modelo estereolitográfico. Int. J. Odontostomat., 9(1):149-152, 2015.

RESUMEN: La reconstrucción maxilar es un procedimiento común en cirugía maxilofacial; para este propósito es utilizado hueso autógeno, hueso aloplástico u otro tipo de hueso con diferentes resultados. En todos ellos, tradicionalmente el uso de tomografía computadorizada se emplea para elaborar el plan quirúrgico, sin embargo, los modelos 3D no son utilizados con frecuencia. Este reporte presenta una nueva aplicación de la estereolitografia para anticipar el tratamiento quirúrgico de la reconstrucción maxilar, usando una malla de titanio y rhBMP-2 para obtener un resultado quirúrgico predecible con disminución del tiempo quirúrgico.

PALABRAS CLAVE: reconstrucción maxilar, rhBMP-2, malla de titanio

\section{REFERENCES}

Arcuri, F.; Baragiotta, N.; Poglio, G. \& Benech, A. Posttraumatic deformity of the anterior frontal table managed by the placement of a titanium mesh via an endoscopic approach. Br. J. Oral Maxillofac. Surg., 50(4):e53-4, 2012.

Kessler, P. \& Hardt, N. The use of micro-titanium mesh for maxillary sinus wall reconstruction. J. Craniomaxillofac. Surg., 24(6):317-21, 1996.

Lee, J. H.; Ryu, M. Y.; Baek, H. R.; Seo, J. H.; Lee, K. M. \& Lee, J. H. Generation of an rhBMP-2-loaded betatricalcium phosphate/hydrogel composite and evaluation of its efficacy on peri-implant bone formation. Biomed. Mater., 9(5):055002, 2014.

Liu, Y. M.; Chen, G. F.; Yan, J. L.; Zhao, S. F.; Zhang, W. M.; Zhao, S. \& Chen, L. Functional reconstruction of maxilla with pedicled buccal fat pad flap, prefabricated titanium mesh and autologous bone grafts. Int. J. Oral Maxillofac. Surg., 35(12):1108-13, 2006.

Louis, P. J.; Gutta, R.; Said-Al-Naief, N. \& Bartolucci, A. A. Reconstruction of the maxilla and mandible with particulate bone graft and titanium mesh for implant placement. J. Oral Maxillofac. Surg., 66(2):235-45, 2008.

Louis, P. J. Vertical ridge augmentation using titanium mesh. Oral Maxillofac. Surg. Clin. North Am., 22(3):353-68, 2010.
Sun, G.; Yang, X.; Tang, E.; Wen, J.; Lu, M. \& Hu, Q. Palatomaxillary reconstruction with titanium mesh and radial forearm flap. Oral Surg. Oral Med. Oral Pathol. Oral Radiol. Endod., 108(4):514-9, 2009.

van den Dolder, J.; Farber, E.; Spauwen, P. H. \& Jansen, J. A. Bone tissue reconstruction using titanium fiber mesh combined with rat bone marrow stromal cells. Biomaterials, 24(10):1745-50, 2003.

Correspondence to:

Prof. Dr. Sergio Olate

Claro Solar 115, Oficina 414-B

Temuco

CHILE

Email: sergio.olate@ufrontera.cl

Received: 23-11-2014

Accepted: 21-03-2015 